\title{
Temperature induced variation in oxygen consumption of juvenile and adult stage of the dog conch Laevistrombus canarium (Linnaeus 1758)
}

\begin{abstract}
Laevistrombus canarium Linnaeus, 1758 is one of the important edible sea snail within the western Johor Straits, Malaysia. In this study, the impact of temperature on oxygen consumption (MO2) of L. canarium based on their ontogenetic changes (juvenile and adult) was measured in the laboratory condition at 22.0, 26.0, 30.0 and $34.0^{\circ} \mathrm{C}$. Measurement of MO2 were taken every $1 \mathrm{~s}$ for $60 \mathrm{~min}$ on $4.20 \mathrm{i} 34.00 \mathrm{~g}$ dog conch using respirometry chamber. All experiments were carried out in static conditions in five replicates with one snail per chambers. The results of oxygen consumption showed that juvenile dog conch respired at the rate of $0.163 \mathrm{ml} \mathrm{hī} 1$ and adult respired at the rate of $0.119 \mathrm{ml} \mathrm{hi} 1$. Consequently, the oxygen consumption in juvenile and adult dog conch was expressed as a total energy spends. The results indicates that total energy spend for oxygen consumed ( $\mathrm{ml}$ hī 1) of L. canarium at different temperature regimes $\left(22.0\right.$ to $\left.34.0^{\circ} \mathrm{C}\right)$ slightly increased over time period $(0.63 \pm 0.12$ to $3.24 \pm 0.05 \mathrm{~J}$ hī 1$)$ respectively. This finding of the present study suggested L. canarium is well adapted for life in high temperature environment.
\end{abstract}

Keyword: Adult; Juvenile; Laevistrombus canarium; Oxygen consumption; Temperature regimes 